\title{
Contamination Status of PCBs and Organochlorine Pesticides in the Okinawa Island, Japan: Utilization of Small Indian Mongoose (Herpestes auropunctatus) as a Bioindicator
}

\author{
Yutaka TASHIRO, Akitoshi GOTO * , Tatsuya KUNISUE * , \\ Takuya KURAHASHI and Shinsuke TANABE * \\ School of International Studies, Meio University \\ (1220-1 Bimata, Nago, Okinawa 905-8585, Japan) \\ * Center for Marine Environmental Studies (CMES), Ehime University \\ (2-5 Bunkyo, Matsuyama, Ehime 790-8577, Japan)
}

[Received January 18, 2016; Accepted July 12, 2016]

\begin{abstract}
Summary
Concentrations of persistent organochlorines (OCs), such as polychlorinated biphenyls (PCBs), dichlorodiphenyltrichloroethane and its metabolites (DDTs), hexachlorocyclohexane isomers $(\mathrm{HCHs})$, hexachlorobenzene $(\mathrm{HCB})$, and chlordane compounds (CHLs) in the muscle and liver tissues of feral mongooses from the Okinawa Island were measured, in order to understand the contamination status by these contaminants in the Southwest Islands, Japan. The lipidnormalized concentrations of each compound were similar between the muscle and liver tissues of mongooses from the rural area, and were in the order of PCBs $>$ CHLs $\fallingdotseq$ DDTs $>\mathrm{HCHs} \doteqdot \mathrm{HCB}$. The concentrations of CHLs and DDTs in the mongoose muscles from the residential areas were higher than those from the rural area. In the mongooses from all the areas, the predominant CHL compounds were oxychlordane and trans-nonachlor, while $p, p$-DDE was dominant among DDTs. Higher concentrations of PCBs were accumulated in the mongooses from an area around a contaminated tidal flat and from another area which includes US military facilities, when compared with those from a residential area. The PCB congeners which occupied more than $5 \%$ of all the congeners detected in the mongoose tissues were PCB138, $153,170,180,187$, and 194 in both of the two highly contaminated areas, but their proportions were different from each other.
\end{abstract}

Key words: Organochlorines, PCB, Mongoose, Okinawa, Military pollution

\section{INTRODUCTION}

Persistent organochlorines (OCs), such as polychlorinated biphenyls (PCBs), dichlorodiphenyltrichloroethane and its metabolites (DDTs), hexachlorocyclohexane isomers (HCHs), hexachlorobenzene (HCB), and chlordane compounds (CHLs) still draw international attention as environmental contaminants, due to their persistency in the environment, bioaccumulative nature, and chronic adverse effects on wildlife and humans. Enormous amounts of technical PCB mixtures and insecticides including DDTs, HCHs, and CHLs were used mainly during the 1960s-70s in Japan. Though the manufacture and use of OCs were banned in many developed countries during the 1970s-80s, relatively high levels of these contaminants have been detected in wildlife, even in recent years ${ }^{1,2)}$.

Japanese Southwest Islands with subtropical or tropical climate are composed of about 200 islands between Japanese main islands and Taiwan including the largest Okinawa Island $\left(1,204 \mathrm{~km}^{2}\right)$. The existence of possible sources of OCs and other hazardous compounds in these islands have been suggested over the last few decades. For example, extremely high concentrations (up to $9 \mathrm{ppm}$ ) of PCBs were found in fish from a coastal area of the Okinawa Island in the 1970s and the leakage from US military stock yards was suggested ${ }^{3)}$. In the 1980s, annual monitoring by the Okinawa Prefectural Government ${ }^{4)}$ reported $\mathrm{PCB}$ concentrations up to $66.1 \mu \mathrm{g} \mathrm{g}^{-1}$ in sediment from a tidal flat in the Okinawa island, which was attributed to the paints containing PCBs used for a bridge over the flat ${ }^{5)}$. Technical CHL mixtures were extensively used as a termiticide in Okinawa until 1986 and elevated concentrations of CHLs has been detected in fish from Okinawan coastal areas ${ }^{6-9)}$. Further, according to a report by the Okinawa General Bureau of the Japanese Cabinet Office in 2014, more than 100 unidentified drum cans were discovered in the underground of a public sports ground on the island, and harmful micropollutants including dioxins, PCBs, and 2,4,5-T were detected from the residual oil in them.

In addition to the possible health risks for the residents on the island, as it is likely that the possible sources of pollution mentioned above are present also in the small islands, the chemicals that polluted the terrestrial environment might have been continuously discharged into the shallow enclosed moats inside the fringing reefs with coral ecosystems of prominent biodiversity ${ }^{10)}$. Coral reefs are one of 
the most biologically productive and diverse ecosystems in the world, and they are important as the basis of marine fisheries and tourism in tropical and subtropical regions. Under such circumstances, information about the sources and distribution of hazardous micropollutants in the environment of the islands is needed for the remediation and redevelopment of the possible polluted areas such as military bases, stock yards, and waste disposal sites.

For the purpose of finding out the point sources of pollutants, sampling of soil in a large study area can give only limited information, especially when the establishment of sampling sites suitable to represent the entire area is difficult due to the limitation of access to some parts of the area such as steep cliff, dense vegetation, and military facility. On the other hand, river water samples from the basin of interest are generally used to figure out the status of pollution. However, as is often the case with coral islands in tropical or subtropical region, the majority of rain water is discharged to the sea as groundwater, hence the researchers face difficulties in establishing adequate sampling sites to track the pollutants throughout the basin.

In order to assess the contamination status in the environment and the risk for wildlife, many biomonitoring studies on OCs have been conducted using tissue samples of various wild animals ${ }^{1,11,12}$. Small Indian Mongooses (Herpestes auropunctatus) were introduced into Okinawa and Amamioshima Islands, Japan, about 100 years ago, and now they extensively inhabit these islands and also inhabit a part of the main land of Japan (Kagoshima Prefecture). Small Indian Mongoose is an omnivorous species which occupy a high trophic position on the islands and feed mainly on reptiles, insects, and small birds. Based on the characteristics that the life span and activity area of the mongoose are within 3-5 years ${ }^{13)}$ and $4 \mathrm{~km}^{2}{ }^{14)}$ respectively, the mongoose can be a useful bioindicator to understand the distinctive regional contamination by various pollutants ${ }^{15}$.

In this study, concentrations of OCs, such as PCBs, DDTs, $\mathrm{HCHs}, \mathrm{HCB}$, and CHLs, in feral mongooses from the Okinawa Island were measured, in order to understand the contamination status by these compounds in the Southwest Islands, Japan. In addition, we verified the existence of potential sources of PCBs by analyzing the sediment from a contaminated tidal flat area.

\section{MATERIALS AND METHODS}

\section{Sample collection}

Muscle tissues of mature male mongooses were obtained from the specimens died from traffic accidents or captured by cage traps during July 2007 to November 2012 from the areas I-IV in Fig. 1. Area I $(n=9)$ is in Kunigami, Higashi, and Ogimi villages where the population densities are low $\left(27,22\right.$, and $51 \mathrm{~km}^{-2}$, respectively) and large proportions of land are covered with woods. Some farms and stock farming facilities are located in this area, while there are no large factories or industrial facilities. Area II $(n=6)$ is composed of the residential areas of two cities on this island, Naha and Nago (downtown area), where the population densities are 8,000 and $5,600 \mathrm{~km}^{-2}$, respectively. Area III $(n=6)$ is in Ginowan and Urasoe cities where the residential areas with small commercial activities are located beside the US military facilities (Futenma Air Base and Camp Kinser). Area IV $(n=4)$ is around a tidal flat in Naha city where sediment pollution by $\mathrm{PCBs}$ was reported previously ${ }^{5}$.
Our previous study ${ }^{16)}$ showed the correlations between body weight and $\mathrm{OC}$ concentrations in the liver of mongooses and the differences in accumulation patterns between male and female mongooses, possibly due to the transfer of OCs from the dam to the offspring during gestation and through lactation. In order to simplify the discussion about the distributions of OC concentrations in the specimens, only mature male samples were analyzed in the present study. Mongooses captured alive by cage traps were sacrificed with $\mathrm{CO}_{2}$ gas within 24 hours after their capture. The specimens were measured, weighted and dissected, except those from area IV which were neither measured nor weighted because of their partial decay and presumed to be adult animals according to their approximate sizes. Muscle tissue from the legs of each specimen and, in the case of area I, liver tissue of the same specimen were collected in plastic bags and all the tissue samples were stored at $-20^{\circ} \mathrm{C}$ until analysis.

Surface sediments were collected using an Ekman dredge at four sites on the tidal flat in area IV in April 2013. Two of these sites were located under a bridge over the flat and other two sites were 0.9 and $1.1 \mathrm{~km}$ upstream of them on the flat, respectively. The sediments were sieved through a 2-mm sieve and centrifuged to remove excess water.

\section{Chemical analysis}

PCBs, DDTs, HCHs, HCB, and CHLs in mongooses were analyzed following the method described previously ${ }^{1}$. Briefly, muscle and liver samples $(5-10 \mathrm{~g})$ were ground with anhydrous sodium sulfate and extracted in a Soxhlet apparatus with a mixture of hexane and diethyl ether. After concentration of the extract, an aliquot was dried at $80^{\circ} \mathrm{C}$ to determine lipid content. Lipid in the remaining extract was

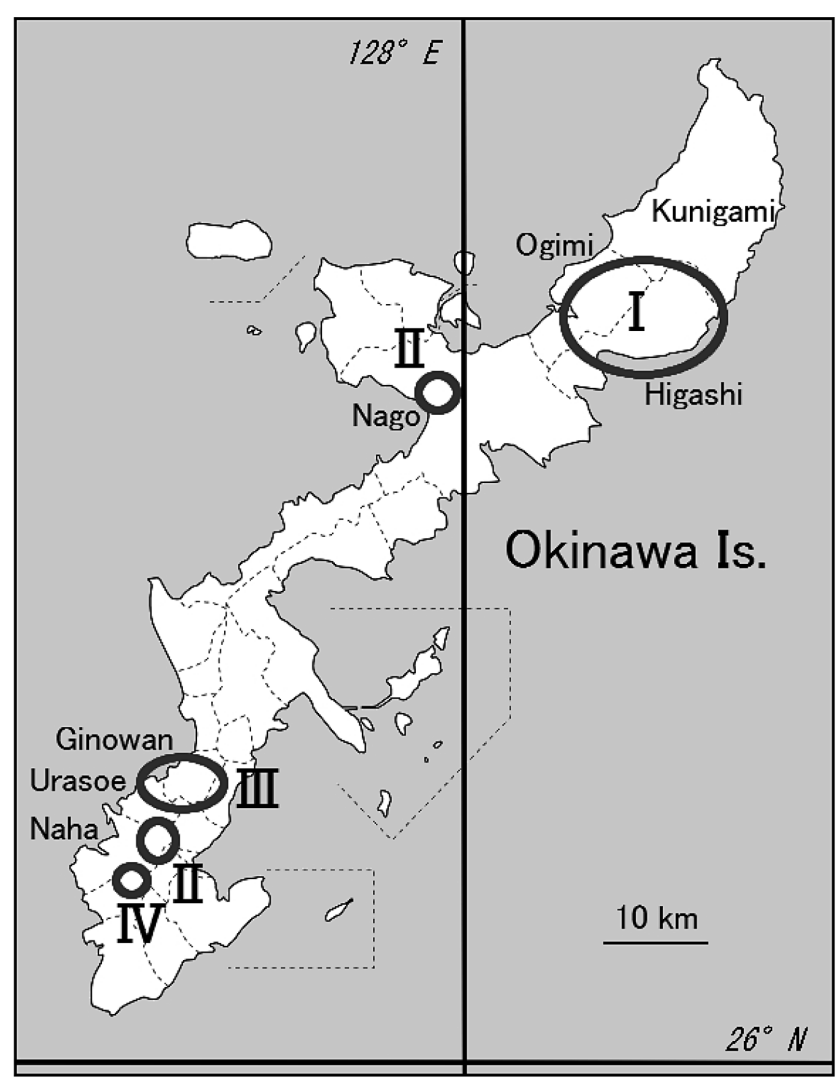

Fig. 1 Sampling location of mongooses analyzed in this study 
removed by gel permeation chromatography (GPC) packed with BioBead S-X 3 (Bio-Rad Laboratories, USA). The lipid removed extract was passed through activated Florisil (Florisil PR: Wako chemicals USA, Inc., USA) packed in a glass column. The first fraction eluted with hexane contained PCBs, HCB, $p, p^{\prime}$-DDE and trans-nonachlor, and the second fraction eluted with $20 \%$ dichloromethane in hexane contained $p, p^{\prime}$-DDT, $p, p^{\prime}$-DDD, HCH isomers ( $\alpha-, \beta$-, and $\gamma$-), cisnonachlor, trans-nonachlor, cis-chlordane, trans-chlordane, oxychlordane. Total PCBs, DDTs ( $p, p^{\prime}$-DDE, $p, p^{\prime}$-DDT and $p, p^{\prime}$-DDD), HCHs $(\alpha-, \beta-$, and $\gamma$-isomers), CHLs (trans-nonachlor, cis-nonachlor, transchlordane, cis-chlordane, oxychlordane) and $\mathrm{HCB}$ were quantified using a gas chromatograph (GC; Agilent 6890 series) equipped with ECD (electron capture detector) and an automatic injector (Agilent 7683 series). The capillary column of GC-ECD was DB-1 (J\&W Scientific) fused silica capillary column $(0.25 \mathrm{~mm}$ x $30 \mathrm{~m})$ coated with $100 \%$ dimethyl polysiloxane at $0.25 \mu \mathrm{m}$ film thickness. The oven temperature was programmed from $70^{\circ} \mathrm{C}$ to $160^{\circ} \mathrm{C}$ at a rate of $10^{\circ} \mathrm{C} / \mathrm{min}$ and held for $10 \mathrm{~min}$. Then the temperature increased to $260^{\circ} \mathrm{C}$ at a rate of $2^{\circ} \mathrm{C} / \mathrm{min}$ with a final hold of $20 \mathrm{~min}$. The temperatures of the injector and detector were set at $260^{\circ} \mathrm{C}$ and $280^{\circ} \mathrm{C}$, respectively. Helium and nitrogen were used as carrier and makeup gases, respectively. The concentration of individual OCs was quantified from the peak area of the samples to that of the corresponding external standard. The PCB standard used for quantification was an equivalent mixture of $62 \mathrm{PCB}$ isomers (BP-MS; Wellington Laboratories Inc., Canada). Peak separation of PCBs were verified for the standard mixture and confirmed to be acceptable for quantification. Identification and quantification of major PCB isomers were confirmed also using a GC-MSD (Agilent 6890 series and 5973 mass selective detector), and achieved similar results as GC-ECD. Some minor PCB congeners contained in commercial PCB products could be eluted together with some of the major congeners under the GC condition described above. However, as the contributions of such congeners in the commercial mixtures were more than one order of magnitude lower in comparison with those of the major congeners ${ }^{17}{ }^{18}$, they were not considered in the quantification of the congeners in this study. Concentrations of individually resolved peaks of $\mathrm{PCB}$ isomers were summed up to obtain total $\mathrm{PCB}$ concentrations. The recoveries of OCs by this method were $97.0 \pm$ 4.2\% for PCBs, $105.0 \pm 5.7 \%$ for DDTs, $98.9 \pm 6.3 \%$ for $\mathrm{HCHs}, 103.9 \pm$ 4.3\% for CHLs and $104.1 \pm 7.9 \%$ for $\mathrm{HCB}$, respectively. Concentrations of $\mathrm{PCBs}$ and $\mathrm{OC}$ pesticides were not corrected for recovery rates. Linearity was confirmed using OC standards in the range of 1.0-1000 $\mathrm{ppb}$. The method limits of detection for OCs were all around $0.5 \mathrm{ng} / \mathrm{g}$ lipid weight based on a signal to noise ratio $(\mathrm{S} / \mathrm{N})$ of 5.0.

For quality assurance and quality control, our research group participated in the Intercomparison Exercise for Persistent Organochlorine Contaminants in Marine Mammal Blubber organized by the National Institute of Standards and Technology (Gaithersburg, MD, USA) and Marine Mammal Health and Stranding Response Program of the National Oceanic and Atmospheric Administration's National Marine Fisheries Service (Silver Spring, MD, USA). Standard reference material SRM 1945 was analyzed for selected PCB congeners and persistent $\mathrm{OC}$ pesticides. Reliable results were obtained by comparison of data from our laboratory with those from standard reference values.

PCBs in sediment samples were analyzed following the method by Okamoto et al. ${ }^{19)}$. About $10 \mathrm{~g}$ of dried sediment sample was ultrasonically shaken with $50 \mathrm{~mL}$ of acetone. After centrifugation, the extract was collected and the sediment was extracted with acetone again. The extracts were combined, and after adding $25 \mathrm{~mL}$ of ethanol, concentrated to $25 \mathrm{~mL}$ under reduced pressure. Twenty-five $\mathrm{mL}$ of $1 \mathrm{M} \mathrm{KOH}$ in ethanol was added and left for one hour in the dark. The extract was transferred to a separation funnel using a $20 \mathrm{~mL}$ mixture of ethanol and hexane (1:1), and $50 \mathrm{~mL}$ of hexane. Fifty $\mathrm{mL}$ of purified water was added, and after partition, hexane layer was transferred to another funnel. The aquatic layer was further extracted with $50 \mathrm{~mL}$ of hexane twice more. Hexane layers were combined, washed with water, and dried with $\mathrm{Na}_{2} \mathrm{SO}_{4}$. After treating with sulfuric acid, the extract was washed again with water, dried with $\mathrm{Na}_{2} \mathrm{SO}_{4}$, and concentrated. Quantification of OCs was performed by injecting an aliquot of the final extract into a GC-ECD. OC pesticides were quantified by comparing individual peak area of sample to the corresponding peak area of the standard. An equivalent mixture of Kanechlor 300, 400, 500 and 600 with known PCB composition and content was used as a PCB standard. Concentrations of individually resolved peaks of $\mathrm{PCB}$ isomers and congeners were summed to obtain total PCB concentrations. The recovery of PCBs by this method was 90.2 $\pm 0.5 \%$. Concentration of PCBs was not corrected for recovery rate.

\section{Statistical analysis}

Kruskal-Wallis test was employed to evaluate differences in organochlorine concentrations among areas and among PCB congeners. Mann-Whitney $U$ test was used for the comparison of the concentrations of PCB congeners between area III and IV. A $p$ value of less than 0.05 was considered to indicate statistical significance. These analyses were executed using SPSS Statistics (IBM Corp.).

\section{RESULTS AND DISCUSSION}

The mean body length and weight of specimens from area I-III are shown in Table 1, and no statistical differences were found among the areas. The concentrations of OCs in mongooses from each area are shown in Table 2. OCs were detected in all the samples analyzed in this study.

\section{$O C$ concentrations in mongooses from a background area (Area l)}

The mean concentration of each compound was similar between the muscle and liver of mongooses from area I, and was in the order of $\mathrm{PCBs}>\mathrm{CHLs} \doteqdot \mathrm{DDTs}>\mathrm{HCHs} \doteqdot \mathrm{HCB}$. This result was in contrast to the findings of Kunisue et al. ${ }^{1)}$ who found that accumulation levels of oxychlordane and $p, p^{\prime}$-DDD in the liver of raccoon dogs were one order of magnitude higher than those in their muscles and suggested preferential hepatic retention of these contaminants. Such phenomenon was not found in the mongooses from area I analyzed in this study, indicating species-specific retention of oxychlordane and

Table 1 Mean \pm SD of body weight and body length of mongooses analyzed in this study

\begin{tabular}{lccc}
\hline & $\mathrm{I}(\mathrm{n}=9)$ & $\mathrm{II}(\mathrm{n}=6)$ & III $(\mathrm{n}=6)$ \\
\hline Body weight $(\mathrm{g})$ & $559 \pm 109$ & $481 \pm 197$ & $650 \pm 65$ \\
Body length $(\mathrm{cm})$ & $544 \pm 35$ & $515 \pm 72$ & $559 \pm 26$ \\
\hline
\end{tabular}


$p, p^{\prime}-\mathrm{DDD}$ in the liver.

Among OCs, PCB concentrations were the highest also in mongoose liver tissues from the same area that we previously analyzed ${ }^{16)}$, and 1-2 orders of magnitude higher levels of PCBs than CHLs, HCHs and $\mathrm{HCB}$ have been reported in liver, adipose, or muscle tissues of Japanese human and avian species ${ }^{11,20}$. These results indicate that the Japanese environment including Okinawa is widely polluted by OCs, especially by PCBs. In contrast, relatively lower concentrations of $\mathrm{HCHs}$ and $\mathrm{HCB}$, in comparison with PCBs and CHLs, were also reported for other wild animals, such as resident birds and raccoon dog, from Japan ${ }^{1,11}$, suggesting less contamination of these compounds for Japanese wildlife. Among $\mathrm{HCH}$ isomers, $\beta-\mathrm{HCH}$ was the most dominant. Such results have been commonly observed in higher trophic animals such as marine mammals without recent exposure to technical $\mathrm{HCH}$ mixture, indicating the persistence of this isomer toward enzymatic degradation ${ }^{21)}$.

$\mathrm{PCB}$ concentrations in mongooses from area I were slightly lower than or comparable to those detected in the adipose tissues of Egyptian mongooses ${ }^{22)}$ from a national park in Spain (mean: $789 \mathrm{ng} \mathrm{g}$ ${ }^{-1}$ lipid wt.) and muscle of raccoon dogs from Kanagawa Prefecture, Japan $^{1)}$ (mean: $270 \mathrm{ng} \mathrm{g}^{-1}$ lipid wt.).

\section{$O C$ concentrations in mongooses from Okinawan residential areas (Areas II-IV)}

As shown in Table 2, concentrations of CHLs in the mongoose muscles from areas II-IV were much higher than those from area I, while the samples from areas III and IV contained statistically higher concentrations of DDTs than those from area I. No statistical differences in concentrations of these contaminants were found among areas II-IV.

The predominant compounds among CHLs were oxychlordane and trans-nonachlor in all the specimens. This result was the same as found in terrestrial mammals from Japan, e.g., muscle or adipose tissues of raccoon dogs from Kanagawa prefecture adjacent to Tokyo ${ }^{1)}$ or from Osaka ${ }^{2)}$, and can be explained as the observations that transnonachlor is highly bioaccumulative and oxychlordane is a stable metabolite of chlordane in higher trophic organisms ${ }^{23}{ }^{24}$. However, it should be noted that CHL concentrations observed in the mongoose muscles from areas II-IV were one order of magnitude higher than those in raccoon dog muscles. The annual surveillance of micropollutants by the Japanese government ${ }^{25,26}$ reported high concentrations of CHLs (39 $\mathrm{ng} \mathrm{g}^{-1}$ in 2012) and DDTs (330 $\mathrm{ng} \mathrm{g}^{-1}$ in 2010) in the sediment of Naha Port where the drain waters from Naha city are discharged. These compounds were used generally as biocides in and

Table 2 Mean \pm SD and range (min-max) concentrations (ng $\mathrm{g}^{-1}$ lipid wt.) of organochlorine compounds in mongooses ${ }^{\mathrm{a}}$

\begin{tabular}{|c|c|c|c|c|c|}
\hline & I (liver, $\mathrm{n}=9$ ) & $\mathrm{I}$ (muscle, $\mathrm{n}=9$ ) & II (muscle, $\mathrm{n}=6$ ) & III (muscle, $\mathrm{n}=6$ ) & IV (muscle, $\mathrm{n}=4$ ) \\
\hline$\overline{\alpha-H C H}$ & $\begin{array}{l}2.7 \pm 4.8 \\
(<0.5-14)\end{array}$ & $\begin{array}{c}<0.5 \\
(<0.5-2.4)\end{array}$ & $\begin{array}{l}<<0.5 \\
(<0.5)\end{array}$ & $\begin{array}{l}0.3 \pm 0.8 \\
(<0.5-2.0)\end{array}$ & $\begin{array}{l}<<0.5 \\
(<0.5)\end{array}$ \\
\hline B-HCH & $\begin{array}{l}10 \pm 12 \\
(<0.5-35)\end{array}$ & $\begin{array}{c}8.0 \pm 8.8 \\
(1.6-29)\end{array}$ & $\begin{array}{l}30 \pm 57 \\
(2.0-170)\end{array}$ & $\begin{array}{l}5.8 \pm 2.2 \\
(3.8-9.9)\end{array}$ & $\begin{array}{l}59 \pm 53 \\
(27-140)\end{array}$ \\
\hline $\mathrm{HCHs}^{b}$ & $\begin{array}{c}12.7 \pm 14.8 \\
(<0.5-42)\end{array}$ & $\begin{array}{c}8.5 \pm 8.4 \\
(2.4-30)\end{array}$ & $\begin{array}{l}30 \pm 57 \\
(2.0-170)\end{array}$ & $\begin{array}{l}6.1 \pm 2.0 \\
(4.2-9.9)\end{array}$ & $\begin{array}{l}59 \pm 53 \\
(27-140)\end{array}$ \\
\hline $\mathrm{HCB}$ & $\begin{array}{c}9.2 \pm 7.5 \\
(2.5-22)\end{array}$ & $\begin{array}{c}5.4 \pm 4.1 \\
(1.0-12)\end{array}$ & $\begin{array}{c}9.6 \pm 17 \\
(1.1-52)\end{array}$ & $\begin{array}{l}3.3 \pm 1.7 \\
(1.9-6.2)\end{array}$ & $\begin{array}{c}6.0 \pm 4.0 \\
(3.5-12)\end{array}$ \\
\hline Oxychlordane & $\begin{array}{c}37 \pm 29 \\
(12-100)\end{array}$ & $\begin{array}{l}33 \pm 57 \\
(5.0-180)\end{array}$ & $\begin{array}{c}2200 \pm 4400 \\
(180-13000)\end{array}$ & $\begin{array}{l}840 \pm 310 \\
(350-1300)\end{array}$ & $\begin{array}{c}1800 \pm 2500 \\
(430-5600)\end{array}$ \\
\hline trans-Chlordane & $\begin{array}{l}<0.5 \\
(<0.5)\end{array}$ & $\begin{array}{l}<0.5 \\
(<0.5)\end{array}$ & $\begin{array}{l}19 \pm 37 \\
(2.4-110)\end{array}$ & $\begin{array}{l}5.8 \pm 7.8 \\
(<0.5-20)\end{array}$ & $\begin{array}{c}27 \pm 12 \\
(15-39)\end{array}$ \\
\hline cis-Chlordane & $\begin{array}{l}<0.5 \\
(<0.5)\end{array}$ & $\begin{array}{l}<0.5 \\
(<0.5)\end{array}$ & $\begin{array}{l}<0.5 \\
(<0.5)\end{array}$ & $\begin{array}{c}53 \pm 30 \\
(19-94)\end{array}$ & $\begin{array}{l}24 \pm 48 \\
(<0.5-97)\end{array}$ \\
\hline trans-Nonachlor & $\begin{array}{l}43 \pm 35 \\
(7.1-110)\end{array}$ & $\begin{array}{l}29 \pm 29 \\
(4.5-86)\end{array}$ & $\begin{array}{c}2800 \pm 4600 \\
(240-13000)\end{array}$ & $\begin{array}{r}1500 \pm 610 \\
(660-2300)\end{array}$ & $\begin{array}{c}2700 \pm 1400 \\
(870-4300)\end{array}$ \\
\hline cis-Nonachlor & $\begin{array}{l}4.9 \pm 4.2 \\
(<0.5-15)\end{array}$ & $\begin{array}{l}4.9 \pm 5.5 \\
(<0.5-14)\end{array}$ & $\begin{array}{c}280 \pm 410 \\
(37-1200)\end{array}$ & $\begin{array}{l}340 \pm 190 \\
(180-640)\end{array}$ & $\begin{array}{l}430 \pm 160 \\
(290-610)\end{array}$ \\
\hline $\mathrm{CHLs}^{\mathrm{b}}$ & $\begin{array}{c}85 \pm 55 \\
(31-190)\end{array}$ & $\begin{array}{l}67 \pm 85 \\
(16-280)\end{array}$ & $\begin{array}{l}7000 \pm 10000 \\
(460-28000)\end{array}$ & $\begin{array}{c}2700 \pm 1100 \\
(1200-4200)\end{array}$ & $\begin{array}{l}5000 \pm 3700 \\
(1700-10000)\end{array}$ \\
\hline pp'-DDE & $\begin{array}{l}44 \pm 20 \\
(21-70)\end{array}$ & $\begin{array}{l}46 \pm 25 \\
(21-97)\end{array}$ & $\begin{array}{l}900 \pm 1600 \\
(140-4900)\end{array}$ & $\begin{array}{c}2300 \pm 3100 \\
(380-8300)\end{array}$ & $\begin{array}{r}1800 \pm 880 \\
(820-2600)\end{array}$ \\
\hline pp'-DDD & $\begin{array}{l}6.2 \pm 7.0 \\
(<0.5-22)\end{array}$ & $\begin{array}{l}3.2 \pm 3.3 \\
(<0.5-9.7)\end{array}$ & $\begin{array}{r}50 \pm 130 \\
(<0.5-380)\end{array}$ & $\begin{array}{c}170 \pm 240 \\
(25-660)\end{array}$ & $\begin{array}{c}64 \pm 18 \\
(39-78)\end{array}$ \\
\hline pp'-DDT & $\begin{array}{l}6.2 \pm 4.6 \\
(<0.5-13)\end{array}$ & $\begin{array}{l}7.6 \pm 11 \\
(<0.5-35)\end{array}$ & $\begin{array}{c}180 \pm 390 \\
(4.2-280)\end{array}$ & $\begin{array}{l}270 \pm 630 \\
(5.0-1600)\end{array}$ & $\begin{array}{l}9.4 \pm 19 \\
(<0.5-38)\end{array}$ \\
\hline $\mathrm{DDTs}^{\mathrm{b}}$ & $\begin{array}{c}56 \pm 25 \\
(26-92)\end{array}$ & $\begin{array}{l}57 \pm 38 \\
(22-140)\end{array}$ & $\begin{array}{c}1300 \pm 2000 \\
(150-5200)\end{array}$ & $\begin{array}{c}2700 \pm 3900 \\
(430-11000)\end{array}$ & $\begin{array}{r}1800 \pm 870 \\
(900-2600)\end{array}$ \\
\hline $\mathrm{PCBs}$ & $\begin{array}{c}160 \pm 130 \\
(19-450)\end{array}$ & $\begin{array}{c}210 \pm 180 \\
(46-630)\end{array}$ & $\begin{array}{l}430 \pm 410 \\
(100-1400)\end{array}$ & $\begin{array}{c}6000 \pm 3900 \\
(680-12000)\end{array}$ & $\begin{array}{l}7800 \pm 5900 \\
(2700-16000)\end{array}$ \\
\hline
\end{tabular}

${ }^{\mathrm{a}} \gamma$ - $\mathrm{HCH}$ and $\delta$-HCH were not detected $\left(<0.5 \mathrm{ng} \mathrm{g}^{-1}\right.$ lipid wt.) from any of the samples.

${ }^{\mathrm{b}} \mathrm{HCHs}=\alpha-\mathrm{HCH}+\beta-\mathrm{HCH}, \mathrm{CHLs}=$ trans-nonachlor + cis-nonachlor + trans-chlordane + cis-chlordane + oxychlordane, DDTs $=p, p^{\prime}-\mathrm{DDE}+p, p^{\prime}-$ $\mathrm{DDT}+p, p^{\prime}-\mathrm{DDD}$. 
around houses and offices in residential areas before their production and use were banned. The higher concentrations of CHLs and/or DDTs detected in the mongooses from areas II-IV in comparison with area I indicate that the environment on the Okinawa Island is still being affected by these compounds.

The composition of DDTs detected in the muscle samples from each area (Fig. 2) showed that $p, p^{\prime}$-DDE was dominant in mongooses from all the areas, as was previously reported in a wide range of wild animals $^{20,27-35)}$. As $p, p^{\prime}$-DDE is a metabolite of $p, p^{\prime}$-DDT, Aguilar ${ }^{36)}$ pointed out that the ratios of $p, p^{\prime}$-DDE/DDTs greater than $60 \%$ may signify a lack of new sources of DDT entering the ecosystem. Moreover, Tavares et al. ${ }^{37)}$ suggested recent use of DDT only when the ratio of $\left[p, p^{\prime}-\mathrm{DDE}+p, p^{\prime}-\mathrm{DDD}\right] / p, p^{\prime}-\mathrm{DDT}$ is less than one. The present study showed that $p, p^{\prime}$-DDE in mongooses from each area occupied more than $79 \%$ to DDTs, and hence it is likely that the elevated concentrations of DDTs in the mongooses from areas III and IV reflected the DDT profiles in organisms (preys) and/or soil rather than to recent spill from DDT stockpile.

In addition, concentrations of PCBs in mongoose muscles from area II were not statistically different from those from area I. This result confirms that the residential areas with only houses and small commercial activities had not been the significant sources of PCBs on the Okinawa Island.

\section{$P C B$ levels and profiles accumulated in mongooses from the areas with specific sources (Areas III and IV)}

The mongooses from area IV around a tidal flat accumulated one order of magnitude higher concentrations of PCBs, compared with those from area I and II. The maximum concentration $\left(16 \mu \mathrm{g} \mathrm{g}^{-1}\right.$ lipid wt.) was three times lower than $50 \mu \mathrm{g} \mathrm{g}^{-1}$ lipid wt., which was the threshold value of reproductive impairment established for the Eurasian otter ${ }^{38}$. PCB contamination of this flat had been reported since early 1980's, and the sediments under a bridge over the flat contained 66.1 and $5.1 \mu \mathrm{g} \mathrm{g}^{-1}$ of PCBs in $1981^{4)}$ and $2001^{5)}$, respectively. As this bridge was constructed in the early 1970's, it was assumed that the PCBs in the paints, which were once used for the bridge and later scratched off for repainting, contaminated the flat sediment in the early 1980 's) ${ }^{5}$. In this study, we found that concentrations of PCBs

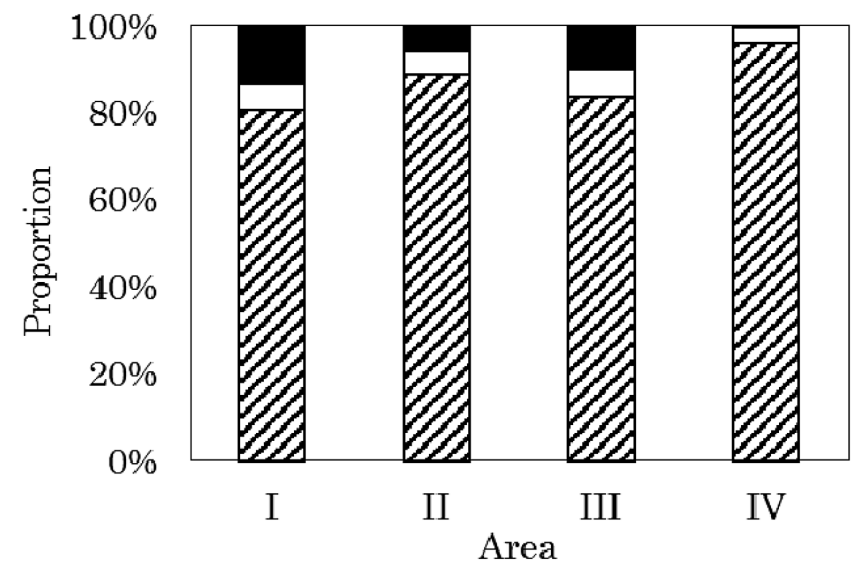

\section{$\square \mathrm{p}, \mathrm{p}^{\prime}-\mathrm{DDE} \square \mathrm{p}, \mathrm{p}^{\prime}-\mathrm{DDD} \boldsymbol{\mathrm { p } , \mathrm { p }}$-DDT}

Fig. 2 Composition of DDTs in mongoose muscles from areas I-IV in the Okinawa Island in the flat sediments collected at two sites under this bridge were 1.0 and $0.40 \mu \mathrm{g} \mathrm{g}^{-1}$, while those in other two sites located 0.9 and $1.1 \mathrm{~km}$ upstream off the bridge were 0.014 and $0.016 \mu \mathrm{g} \mathrm{g}^{-1}$, respectively. The mongooses were obtained at the sites which were beside the flat and located 1.1-1.4 $\mathrm{km}$ upstream off the bridge. Considering that area IV is a residential area like area II, PCBs diffused from the bridge to the entire flat were supposed to be the principal source for the area IV specimens.

The mongoose tissues from area III contained almost the same amount of PCBs as those from area IV. Area III is also a residential area as areas II and IV, where any environmental contamination by PCBs has not been reported before. As no possible sources of PCBs such as heavy industrial activities nor dumping fields exist in this area except the presence of US military facilities, the observations in mongooses from area III indicate the existence of significant PCB pollution sources in this area presumably derived from these facilities. As the PCB levels detected in the mongooses from area III and IV were almost the same, contamination in area III might be of similar significance as in the sediment of the flat in area IV, i.e., with the order of 1 $\mu \mathrm{g} \mathrm{g}^{-1}$ of PCBs in surface sediment or soil.

The PCB congeners which occupied more than $5 \%$ of all the congeners detected in the mongoose tissues were PCB138, 153, 170, 180, 187, and 194 in both the highly contaminated areas III and IV. These highly chlorinated congeners were commonly found in the tissues of various species including terrestrial mammals as major PCB congeners $\left.{ }^{22,} 27,29,35,39\right)$; however, their proportions were different between these two areas. Figure 3 shows the relative concentration of these congeners to PCB180 detected in mongooses from each area. The concentration of PCB153 in area III specimens was statistically higher than PCB180, while these two congener levels were similar in area IV mongooses.

As PCBs in the sediment of the tidal flat is considered as one of the major sources for area IV mongooses, the congener profile in the most contaminated sediment sample from the tidal flat is shown in Fig. 4 for comparison. PCB congeners which occupied more than $5 \%$ of the total PCBs detected in the sediment were in the order of PCB180, $138,153,170$, and 187 . Such predominance of highly chlorinated congeners was often reported for a wide range of sediment samples in-

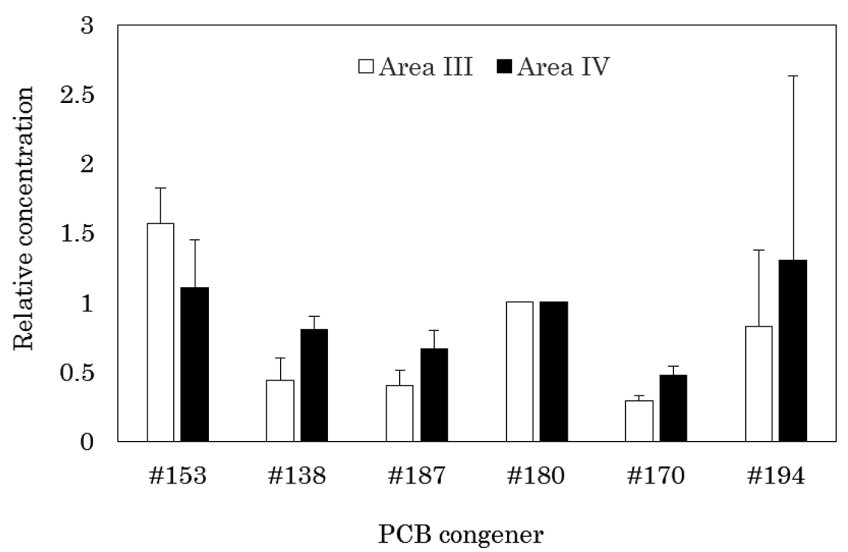

Fig. 3 PCB congener patterns in mongoose muscles from area III and IV of the Okinawa Island. Relative concentration indicates ratio of individual congener concentration to that of PCB180, which was treated as 1 


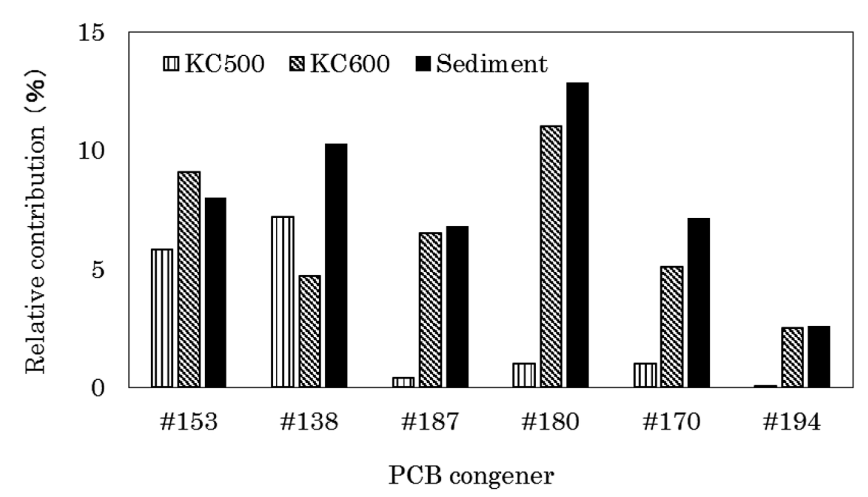

Fig. 4 Relative contribution of major congeners to total PCB concentration in sediment from area IV and Kanechlor products $^{43}$

cluding one sample collected from the area IV in 2001, and explained by their persistence in the environment and abundance in commercial PCB products such as Kanechlor KC500 and KC600 5, 40-43). The PCB congener profiles in Fig. 4 shows a similarity between the sediment and $\mathrm{KC} 600$, suggesting the contribution from this product as the origin of contamination in the sediment. As the high content of PCB180 is characteristic of KC600, PCB180 concentration comparable to PCB153 in the sediment and mongoose from area IV can be explained by such proportion of congeners in the origin. In contrast, the larger concentration of PCB153 than PCB180 in the mongooses from area III suggests that the origin of PCBs accumulated in their tissues were different from those in the sediment from area IV and might include PCB products used for other purposes such as dielectric fluids in transformers or lubricant oils.

The mongoose tissues from areas III and IV contained considerable concentrations of PCB194 with relatively large variations. Although this reason is unclear, some mongooses inhabiting areas III and IV might be specifically exposed to PCB194 and/or this congener may be persistent in Herpestidae family. Relatively high concentrations of PCB194, in addition to PCB180, were observed also in canine species $^{27,29)}$.

\section{CONCLUSIONS}

The analyses of mongoose tissues in the present study showed that the terrestrial environment in the rural area of Okinawa, like other parts of Japan, was polluted by OCs, especially by PCBs. In addition, it was found that the urban areas of Okinawa were contaminated more by DDTs and CHLs than the rural areas. The high concentration of CHLs in the mongooses from Okinawan urban areas, which can be related to the high rate usage of termicides under the subtropical climate there, emphasizes the importance of management for environmental issues specific to each region, and imposes the further investigations on CHL pollution in Okinawa and other Southwest Islands of Japan.

The present study demonstrated the efficiency of chemical analyses using tissues collected from wild terrestrial animals, as a measure to search pollution sources within their activity areas, even where it is difficult for researchers to access. The results observed in the mongooses from area III suggest the existence of unknown or undisclosed specific sources of PCB pollution in this area. Such pollution is not found commonly in other Okinawan residential areas, therefore, the sources are supposed to be inside the military facility in this area where only wild animals can enter, as the information about the storage of hazardous compounds or the environmental issues inside the US military facilities are rarely transmitted to the local government or citizens. As mongooses widely inhabit South East and South Asia, this wild species can be a useful bioindicator to collect information about unknown terrestrial pollution of OCs in the Asian regions.

\section{ACKNOWLEDGEMENTS}

Authors are grateful to late Dr. Go Ogura from the Faculty of Agriculture of the University of the Ryukyus, Naha Nature Conservation Office of Japanese Ministry of the Environment, and Nansei Environmental Laboratory Co., Ltd. for their kind helps for sample collection. This study was supported by JSPS KAKENHI (C) Grant Number 25340062 and by the Ministry of Education, Culture, Sports, Science and Technology, Japan (MEXT) to a project on Center of Excellence for Cooperative and Collaborative Studies - Leading Academia in Marine and Environmental Research (LaMer).

\section{REFERENCES}

1) Kunisue, T., Takayanagi, N., Tsubota, T. and Tanabe, S.: Persistant organochlorines in raccoon dogs (Nyctereutes procyonoides) from Japan: Hepatic sequestration of oxychlordane. Chemosphere, 66, 203-211 (2007)

2) Kunisue, T., Takayanagi, N., Isobe, T., Takahashi, S., Nakatsu, S., Tsubota, T., Okumoto, K., Bushisue, S., Shindo, K. and Tanabe, S.: Regional trend and tissue distribution of brominated flame retardants and persistent organochlorines in raccoon dogs (Nyctereutes procyonoides) from Japan. Environ. Sci. Technol., 42, 685-691 (2008)

3) Kinjo, K., Yamashiro, Y. and Uehara, T.: Monitoring of PCBs and heavy metals in fish (3) (in Japanese). Report of Okinawa Prefectural Institute of Health and Environment, 11, 74-75 (1977)

4) Okinawa Prefectural Government: Annual Report of Water Quality Monitoring (in Japannese). Okinawa Prefectural Government, Okinawa (1980-2002)

5) Tashiro, Y., Takahira, K., Osada, H., Fuji, H. and Tokuyama, A.: Distribution of polychlorinated biphenyls (PCBs), lead, and cadmium in Manko tidal flat, Okinawa. Limnology, 5, 177-183 (2004)

6) Ohshiro, Y.: Chlordane and environmental pollution (1) -analytical method and contamination status- (in Japanese). Report of Okinawa Prefectural Institute of Health and Environment, 14, 1-16 (1981)

7) Konishi, Y., Kuwabara, K. and Hori, S.: Continuous surveillance of organochlorine compounds in human breast milk from 1972 to 1998 in Osaka, Japan. Arch. Environ. Contam. Toxicol., 40, 571578 (2001)

8) Tanabe, S., Takahashi, S., Malarvannan, G., Ikemoto, T., Anan, Y., Kunisue, T., Isobe, T. and Agusa, T.: Survey on hazardous chemicals in aquatic organisms inhabiting Nansei Shoto Islands: Report on the contamination status of fish and shellfish. pp. 2546, "Wildlife Contamination Assessment of Nansei Shoto Islands (2005-2007)", WWF Japan, Tokyo (2008)

9) Oshiro, Y., Uechi, S., Asato, N., Kinjo, K., Yoshida, N., Toguchi, A., 
Tamaki, F., Futenma, T., Miyagi, T. and Uehara, T.: Environmental survey and monitoring of chemicals in Okinawa (1995-2004) (in Japanese). Report of Okinawa Prefectural Institute of Health and Environment, 40, 179-186 (2006)

10) Roberts, C.M., McClean, C.J., Veron, J.E.N., Hawkins, J.P., Allen, G.R., McAllister, D.E., Mittermeier, C.G., Schueler, F.W., Spalding, M., Wells, Vynne, F., C. and Werner, T.B.: Marine biodiversity hotspots and conservation priorities for tropical reefs. Science, 295, 1280-1284 (2002)

11) Kunisue, T., Watanabe, M., Subramanian, A., Sethuraman, A., Titenko, A. M., Qui, V., Prudente, M. and Tanabe, S.: Accumulation features of persistent organochlorines in resident and migratory birds from Asia. Environmental Pollution, 125, 157-172 (2003)

12) Watanabe, M., Iwata, H., Watanabe, M., Tanabe, S., Subramanian, A., Yoneda, K. and Hashimoto, T.: Bioaccumulation of organochlorines in crows from an Indian open waste dumping site: evidence for direct transfer of dioxin-like congeners from the contaminated soil. Environ. Sci. Technol., 39, 4421-4430 (2005)

13) Japanese Ministry of Environment, Kagoshima Prefecture, Japan Wildlife Research Center: Report on the model project for extermination and control of alien species on islands (Amami Island; mongoose) (in Japanese). Japanese Ministry of Environment, Tokyo (2000)

14) Okinawa Prefectural Government: Report on the mongoose control measures, FY2002 (in Japannese). Okinawa Prefectural Government, Okinawa (2003)

15) Horai, S., Minagawa, M., Ozaki, H., Watanabe, I., Takeda, Y., Yamada, K., Ando, T., Akiba, S., Abe, S. and Kuno, K.: Accumulation of $\mathrm{Hg}$ and other heavy metals in the Javan mongoose (Herpestes javanicus) captured on Amamioshima Island, Japan. Chemosphere, 65, 657-665 (2006)

16) Tashiro, Y., Ogura, G., Kunisue, T. and Tanabe, S.: Persistent Organochlorines Accumulated in Small Asian Mongoose (Herpestes javanicus) from the Yambaru Area, Okinawa, Japan. Jpn. J. Zoo. Wildl. Med., 16, 65-70 (2011)

17) Schulz, D.E., Petrick, G. and Duinker, J.C.: Complete characterization of polychlorinated biphenyl congeners in commercial Aroclor and Clophen mixtures by multidimensional gas chromatography-electron capture detection. Environ. Sci. Technol., 23, 852-859 (1989)

18) Takasuga, T., Kumar, K.S., Noma, Y. and Sakai, S.: Chemical characterization of polychlorinated biphenyls, -dibenzo-p-dioxins, and -dibenzofurans in technical Kanechlor PCB formulations in Japan. Arch. Environ. Contam. Toxicol., 49, 385-395 (2005)

19) Okamoto, K., Yasuhara, A., Nakano, T., Kenmotsu, K., Matsumura, T., Yagi, T., Kakita, K., Ono, A. and Sakata, M.: Comparison study on the condition of alkaline treatment in case of determination of PCBs in river sediment (in Japanese). Bunseki Kagaku, 52, 61-66 (2003)

20) Minh, T.B., Watanabe, M., Tanabe, S., Yamada, T., Hata, J. and Watanabe, S.: Specific accumulation and elimination kinetics of tris(4-chlorophenyl)methane, tris(4-chlorophenyl)methanol, and other persistent organochlorines in humans from Japan. Environ. Health Perspect, 109, 927-935 (2001)

21) Minh, T.B., Watanabe, M., Nakata, H., Tanabe, S. and Jefferson,
T.A.: Contamination by persistent organochlorines in small cetaceans from Hong Kong coastal waters. Mar. Pollut. Bull., 39, 383-392 (1999)

22) Mateo, R., Milian, J., Rodriguez-Estival, J., Camarero, PR., Palomares, F. and Ortiz-Santaliestra, M.E.: Levels of organochlorine pesticides and polychlorinated biphenyls in the critically endangered Iberian lynx and other sympatric carnivores in Spain. Chemosphere, 86, 691-700 (2012)

23) Nakata, H., Tanabe, S., Tatsukawa, R., Amano, M., Miyazaki, N. and Petrov, E.A.: Persistent organochlorine residues and their accumulation kinetics in Baikal Seal (Phoca sibirica) from Lake Baikal, Russia. Environ. Sci. Technol., 29, 2877-2885 (1995)

24) Bondy, G.S., Newsome, W.H., Armstrong, C.L., Suzuki, C.A., Doucet, J., Fernie, S., Hierlihy, S.L., Feeley, M.M. and Barker, M.G: Trans-Nonachlor and cis-Nonachlor Toxicity in SpragueDawley Rats: Comparison with Technical Chlordane. Toxicological Sciences, 58, 386-98 (2000)

25) Japanese Ministry of the Environment: Chemicals in the environment: Report on environmental survey and monitoring of chemicals, FY2012 (in Japanese). Japanese Ministry of Environment, Tokyo (2014)

26) Japanese Ministry of the Environment: Chemicals in the environment: Report on environmental survey and monitoring of chemicals, FY2010 (in Japanese). Japanese Ministry of Environment, Tokyo (2012)

27) Hoshi, H., Minamoto, N., Iwata, H., Shiraki, K., Tatsukawa, R., Tanabe, S., Fujita, S., Hirai, K. and Kinjo, T.: Organochlorine pesticides and polychlorinated biphenyl congeners in wild terrestrial mammals and birds from chubu region, Japan: Interspecies comparison of the residue levels and compositions. Chemosphere, 36, 3211-3221 (1998)

28) Santos, X., Pastor, D., Llorente, G.A. and Albaigés, J.: Organochlorine levels in viperine snake Natrix maura carcasses from the Ebro Delta (NE Spain): sexual and size-related differences. Chemosphere, 39, 2641-2650 (1999)

29) Corsolini, S., Burrini, L., Focardi, S. and Lovari, S. How can we use the red foxes as a bioindicator of organochlorine? Arch. Environ. Contam. Toxicol., 39, 547-556 (2000)

30) Kajiwara, N., Ueno, D., Monirith, I., Tanabe, S., Pourkazemi, M. and Aubrey, D.G.: Contamination by organochlorine compounds in sturgeons from Caspian Sea during 2001 and 2002. Marine Pollution Bulletin, 46, 741-747 (2003)

31) Kajiwara, N., Watanabe, M., Wilson, S., Eybatov, T., Mitrofanov, I.V., Aubrey, D.G., Khuraskin, L.S., Miyazaki, N. and Tanabe, S.: Persistent organic pollutants (POPs) in Caspian seals of unusual mortality event during 2000 and 2001. Environmental Pollution, 152. 431-442 (2008)

32) Allinson, G., Mispagel, C., Kajiwara, N., Anan, Y., Hashimoto, J., Laurenson, L., Allinson, M. and Tanabe, S.: Organochlorine and trace metal residues in adult southern bent-wing bat (Miniopterus schreibersii bassanii) in southeastern Australia. Chemosphere, 64, 1464-1471 (2006)

33) Malarvannan, G., Takahashi, S., Isobe, T., Kunisue, T., Sudaryanto, A., Miyagi, T., Nakamura, M., Yasumura, S. and Tanabe, S.: Levels and distribution of polybrominated diphenyl ethers and organochlorine compounds in sea turtles from Japan. Marine 
Pollution Bulletin, 63, 172-178 (2011a)

34) Malarvannan, G., Takahashi, S., Ikemoto, T., Isobe, T., Kunisue, T., Sudaryanto, A., Miyagi, T., Nakamura, M., Yasumura, S. and Tanabe, S.: Contamination status and spatial distribution of organochlorine compounds in fishes from Nansei Islands, Japan. Marine Pollution Bulletin, 63, 541-547 (2011b)

35) Tomza-Marciniak, A., Marciniak, A., Pilarczyk, B., Prokulewicz, A. and Bąkowska, M.: Interspecies comparison of chlorinated contaminant concentrations and profiles in wild terrestrial mammals from Northwest Poland. Arch. Environ. Contam. Toxicol., 66, 491-503 (2014)

36) Aguilar, A.: Relationship of DDE/ $\mathrm{DDDT}$ in marine mammals to the chronology of DDT input into the ecosystem. Can. J. Fish. Aquat. Sci., 41, 840-844 (1984)

37) Tavares, T., Beretta, M. and Costa, M.: Ratio of DDT/DDE in the all Saints Bay, Brazil and its use in environmental management. Chemosphere, 38, 1445-1452 (1999)

38) Mason, C.F. and Wren, C.D.: Carnivora. pp.315-170, "Ecotoxicology of Wild Mammals" Edited by Shore, R.F. and Rather, B.A., John Wiley and Sons Ltd., Chichester, UK, (2001)

39) Georgii, S., Bachour, Gh., Failing, K., Eskens, U., Elmadfa, I. and Brunn, H.: Polychlorinated biphenyl congeners in foxes in Germany from 1983 to 1991. Arch. Environ. Contam. Toxicol., 26, 1-6
(1994)

40) Covaci, A., Gheorghe, A., Voorspoels, A., Maervoet, J., Redeker, E.S., Blust, R. and Schepens, P.: Polybrominated diphenyl ethers, polychlorinated biphenyls and organochlorine pesticides in sediment cores from Western Scheldt River (Belgium): analytical aspects and depth profiles. Environ. Int., 31, 367-375 (2005)

41) Ilyas, M., Sudaryanto, A., Setiawan, I.E., Riyadi, A.S., Isobe, T., Takahashi, S. and Tanabe, S.: Characterization of polychlorinated biphenyls and brominated flame retardants in sediments from riverine and coastal waters of Surabaya, Indonesia. Marine Pollution Bulletin, 62, 89-98 (2011)

42) Kanzari, F., Syakti, A.D., Asia, L., Malleret, L., Pirama, A., Mille, G. and Doumenqa, P.: Distributions and sources of persistent organic pollutants (aliphatic hydrocarbons, PAHs, PCBs and pesticides) in surface sediments of an industrialized urban river (Huveaune), France. Science of the Total Environment, 478, 141151 (2014)

43) Takasuga, T., Senthilkumar, K., Matsumura, T., Shiozaki, K. and Sakai, S.: Isotope dilution analysis of polychlorinated biphenyls (PCBs) in transformer oil and global commercial PCB formulations by high resolution gas chromatography-high resolution mass spectrometry, Chemosphere, 62, 469-484 (2006) 